\title{
DIRECTING THE FUTURE OF GENE THERAPY IN CYPRUS: Breakthroughs, Subjunctivities, and the Pragmatics of Narrative
}

\author{
THEODOROS KYRIAKIDES \\ University of Cyprus \\ (iD) http://orcid.org/0000-0001-8862-5096
}

Thalassemia is a recessive blood disorder particularly prevalent in countries of the Mediterranean Basin. Sixteen percent of the population of Cyprus carries the thalassemia trait - the second-highest percentage in the world after the Maldives. Combined with Cyprus's small size, the potential for couples to have thalassemic infants is very high. Although significant advances have been made, the main methods used to treat thalassemia today are the same as those used when it was first discovered. These treatment methods consist of weekly or biweekly blood transfusions and the daily use of a dialysis pump for the excretion of excess iron that results from such frequent transfusions.

Soon after Cyprus became an independent nation in 1960, Cypriot health officials faced the urgent question of how to prevent the birth of thalassemic infants. Such urgency was accentuated by a World Health Organization (WHO) report estimating that, unless action was taken, the increased blood supply needed for transfusions would prove an unbearable burden to the public health-care system over time (Angastiniotis, Kyriakidou, and Hadjiminas 1986). Since the 1970s, the implementation of a successful prevention system has minimized the birth of thalassemic infants. Although this is in many ways a positive development, it has also left about six hundred thalassemia patients on the island, who were born 
before the prevention system was in place, in the precarious situation of having continuously to negotiate and contest their position within state budgets regarding new forms of thalassaemia treatment. This is also the case for those seeking genetherapy treatment. Gene therapy is a technology that involves the introduction of therapeutic genes into the human body to replace mutations causing disorders (Addison 2017). In the case of thalassemia, the introduction of healthy genes could help patients' bodies begin producing hemoglobin at higher rates, thereby eliminating or reducing the need for regular blood transfusions and dialysis.

This article, stemming from research conducted with a thalassemia patients' association in Cyprus from July 2012 to September 2013, explores how the political and epistemic uncertainty surrounding the promise of breakthroughs in gene therapy is harnessed to particular political objectives and narratives of the future. In what follows, I focus on the activities of the Pancyprian Thalassemia Association (PTA). The PTA is the main channel of politicization for thalassemia patients in Cyprus and maintains an agonistic relationship with the state. Through several bouts over time with the Cypriot Ministry of Health, it has managed to provide better health-care conditions for thalassemia patients by improving aspects of treatment such as blood supply, hospital space, and provisions for dialysis. In the context of this article, I explore the politics of thalassemia gene therapy in Cyprus through the alliance between the PTA and the Cypriot Institute of Neurology (CING) — a private, but largely government-funded research center.

During my fieldwork, a breakthrough regarding the prospect of gene therapy for thalassemia became a recurrent topic of conversation and events, which was generative of political deliberation among PTA members, CING scientists, and Cypriot health officials. As the patient and PTA narratives presented in this article will convey, critique and contestation have resulted from the state's unwillingness to provide the necessary funding and infrastructure for the public health-care system to receive and implement gene therapy once it becomes available. The unwillingness and, arguably, the inability of the state to appease the demands of thalassemia patients regarding gene therapy must be considered in relation to the Cypriot context. Cyprus has particularly suffered under austerity politics in recent years. During my fieldwork in March 2013, the European Commission, European Central Bank, and the International Monetary Fund (IMF) provided a financial bailout for the country. Consequent terms demanded that the government increase taxes and cut expenditures on several fronts, including health care. Amid such conditions, the promise of gene therapy in Cyprus was cast into further doubt. 
In a foundational essay on the anthropology of the future, Jane Guyer (2007, 409) argued that the near future - the middle ground between "immediate situations" and the "very long-term horizon"_-remains increasingly absent in political practices and public narratives. We can understand Guyer's analysis as an ethnographic indication of contemporary modes of future-making, but perhaps also as a call for further anthropological theorization of how individuals and collectives develop the means to orient themselves amid chronic uncertainty. Both prior to and after the publication of Guyer's essay, anthropologists have conceptually populated this middle ground with notions of waiting (Hage 2009; Brun 2015; Kwon 2015; Sandoval-Cervantes 2017; Zee 2017), hope (Miyazaki 2004; Reed 2011; Jansen 2016), patience (Appadurai 2013; Procupez 2015), and endurance (Ringel 2014). As I suggest in this article, while such notions showcase the active stance adopted by individuals and collectives in handling uncertainty, their analytical use can obscure the dynamics of alliance through which such practices are afforded political vitality, as well as the particular goals for the future toward which they are directed.

Relatively little ethnographic attention has been given to the methods by which people organize possibility and uncertainty through constructing and deploying narratives of the future that are capable of bridging and proliferating relations between present immediacy and abstract futurity - a process I call directing the future. The concept used in this article to elucidate these connections between breakthrough and narrative is that of the subjunctive. Ethnographic treatments of subjunctivity regard it as a mode of subjectivity inclined toward possibility. Nevertheless, the sociopolitical dynamics that make subjunctivity possible, as well as varying degrees of subjunctivity, are often obfuscated by an ethnographic emphasis on open-endedness and hope. Rather than celebrating the evocation of possibility that the subjunctive effects, I focus on the existential, relational, and political conditions of contestation through which modalities of subjunctivity emerge and are sustained. I argue that subjunctivity does not merely represent the ability to be receptive to transformation and the possibility of an alternative world. By juxtaposing the varying positionalities that thalassemia patients in $\mathrm{Cy}$ prus adopt regarding the promise of gene therapy, I show how the intersubjective and political processes out of which subjunctivity and narrative emerge also constitute the processes by which an otherwise undefined future becomes ordered, as certain images of the future attain more gravity and reality than others. 


\section{THINKING THE BREAKTHROUGH}

As the historical and recent (post-1930s) use of the word suggests, breakthrough as a technoscientific object and keyword of public discourse is specific to societies structurally geared toward generating scientific and technological advancement (Kuhn 1962; Nowotny, Scott, and Gibbons 2003). Visions of the future are intimately tied to such expectations of technological advancement and what is broadly understood and referred to as progress (Franklin 1998). Peter Pels $(2015,787)$ correctly observes that discourses of social and technological acceleration are not especially recent. Nevertheless, the ontological dynamics of the breakthrough are of a particular nature, as they put humanity in conversation not only with an open future and its politics but also with its limits of worldly understanding. Modern science and biomedicine do not constitute processes of linear technological advancement so much as they more intensely put humanity in conversation with the "outside" (Jensen 2013) — in other words, that which remains external and irreducible to the human grasp of the world. Whereas notions of progress embedded in historical processes of exploration and discovery were produced through the "geographical opening up of the globe" (Pels 2015, 785), discourses on breakthrough, emanating largely from the natural sciences, emerge from a human acceptance of incomplete mastery and knowledge of the world (Barad 2007; Helmreich 2009).

Pharmaceutical capitalism expands by appropriating such epistemic uncertainty and ontological opacity. In biomedicine, a field in which breakthrough makes for an especially resonant term, technological progress and intensifying flows of pharma-financialization (Sunder Rajan 2006) have transformed the human body into a pool of therapeutic potentiality (Thompson 2005; Taussig, Hoeyer, and Helmreich 2013), but also an instrument of commodification (Rose and Rose 2012). Several scholars have demonstrated that our increasing involvement with therapeutic technologies fosters the development of a more direct relationship with the future (Ginsburg and Rapp 1995; Biehl and Locke 2010; Gammeltoft 2013). Nevertheless, a track record of technological failure has made evident the problematic character of biomedical messianism (Petryna 2010). This holds especially true for gene therapy, which has been in development since the early 1990s. Despite such a long trajectory, clinical trials still in development, and the deaths of two patients on separate occasions (Addison 2017), recent advances in the field of targeting and delivery of viral vectors have left pharmaceutical companies scurrying to patent various forms of gene therapy for the treatment of diseases. 
Within an abstract temporality of the future, narratives and expectations of breakthrough operate and flourish according to a vague affect of agitation and promise. When will the breakthrough come? What will it be able to achieve once it arrives? The breakthrough acquires its force through these queries. Epistemic ambivalence surrounding the coming of breakthroughs infuses the temporal trajectory by which they unfold with considerable political vitality. As Alberto Corsín Jiménez (2014) suggests, a "prototype" technology such as gene therapy constitutes a field of experimentation that is in a constant state of becoming, generative of new modes of politics and knowledge. I embrace Corsín Jiménez's suggestion of a sociotechnical field of perpetual generativity, but I also aim to explore the political and cognitive processes that restrict such generativity. What I regard as a directed modality of future-making requires not only the continuous production of possibility but also its channeling into particular political objectives for the future. Hence, on the one hand, gene therapy can indeed be conceptualized as a technology that, courtesy of an ongoing process of experimentation and development, produces a series of political processes aimed at negotiating and contesting its public standing and use. On the other hand, for those seeking some degree of certainty that the technology will some day extend beyond its prototypical stage, the field of possibility must not only be politically protected and cultivated but also managed and demarcated through particular narratives of the future.

\section{HOW TO BREAK THROUGH}

The first time I heard about gene therapy was when I spoke to M., a mother of one, in a downtown Nicosia café. She did not know much about it except that "gene therapy was coming." M. was working in an accounting firm and was open about her condition as a thalassemia patient. As I learned soon after commencing fieldwork, such was not always the case: although treatment for thalassemia patients in Cyprus has greatly improved over time, specters of social stigma persist, especially around employment and personal relationships. Numerous thalassemia patients told me how they would often face prejudice in job interviews, or how potential partners would walk away when they disclosed their illness. M. seemed proud of the way in which she carried herself publicly because, despite thalassemia, she had a successful career and marriage.

I asked M. about her daily treatment routine. She told me that she used a combination of iron chelation pills and pumps to get rid of excess iron in her body. She casually mentioned gene therapy in the middle of our conversation: 
"And then you have all that talk about gene therapy and whatnot." ${ }^{1}$ She stopped talking and took a sip of coffee, so I asked her what that was. From the things M. had heard from other patients and read on the Internet, she gathered that "the way it works is they put good genes into your body to replace the bad genes," and after that, "your body starts producing hemoglobin again." She continued: “To be honest, I don't follow all that talk-I am content with my therapy right now . . . Things are much better than they used to be when I was a childtherapy methods are much better, and if you follow them routinely, you can pretty much lead a normal life." She then made a gesture of dismissal with her hands, her palms cyclically swirling in mid-air, denoting futility and the passage of time. She explained to me that the she had been hearing rumors of gene therapy becoming available "for eons now." I asked why she did not seem interested in learning more about it. She blew smoke, stubbed out her cigarette in the ashtray, and shrugged her shoulders. "There are some seminars I could go to, but to be honest, I don't see the point in finding out more about it. If it comes, it comes. If they manage to make a breakthrough, I'll find out about it.”

As I came to understand through the progression of my fieldwork, M. was one of the few patients in Cyprus who was not part of the PTA. As M. explained: "I don't feel like I should be part of an association just because some other person and I have the same disease. Of course, I know others who have thalassemiateachers, journalists, government employees, and even judges - but if I want to talk to them or meet for a coffee, I'll just give them a call.” She concluded that, “as long as I am doing fine with my treatment, I don't see why I should spend more of my time on other things having to do with thalassemia." When I asked if she knew other thalassemia patients I could talk to, M. directed me to a friend of hers. She said that she knew this woman from the thalassemia clinic in Nicosia, where patients go to have their transfusions and to get their blood checked periodically. The two would sometimes arrange to meet at the clinic if their schedules allowed, and chat for the three or so hours of the transfusion.

Much like M., her friend cited lack of time as her reason for not joining the association. "I pay a small subscription, but that's it really," she explained. "I have to deal with this disease every day-I don't want to do it in my free time also." At some point, I asked her what she knew about the potential of gene therapy implementation in Cypriot health care. Like M., the woman did not seem particularly knowledgeable on the subject, or interested: “I don't know much about it. I know that some scientists at CING are working on it, but that nothing 
is really for sure. These kinds of things, only doctors know what they are really about - we only keep hearing that they are working on it."

There was not much else to be said on that point, so I posed a speculative question: "If it became available on a widespread basis at some point, would you go for it?" She remained silent and pondered the question for a second or two. Eventually, she replied: "I don't think I would. I've made a life for myself, my current treatment is working, and I got used to it, so I don't see why I should go around changing that. Who knows what effects gene therapy might have on your body?" She continued: "We are the second generation of thalassemics to have been lucky to receive treatment in Cyprus. I was born in 1975-I feel lucky because it was much harder to get medical treatment before then. And the other thing is that everyone - my friends, family, colleagues - know I am a thalassemic. I have no need to hide it like people used to do before." After some further seconds of silence, she went on to add: "I would consider [gene therapy]. If it had a high success rate, say 99 percent, then I would probably try it." Our conversation ended with a note of doubt: "Our doctors try to stay up to date with what's happening, and they go to seminars and educate themselves about what's new in gene therapy. But there's still nothing here for us in Cyprus. We are depending on research centers from other countries to make the breakthrough.”

\section{MAKING FRIENDS}

My initial conversations unveiled uncertainties about the prospect of breakthrough. For the two interlocutors I have introduced above, such uncertainty was above all specific to Cyprus: the dire economic state of Cypriot health care offered little hope for the promise of gene therapy becoming accessible in the future. At the same time, such uncertainty extended beyond the Cypriot context and gestured to gene therapy's long trajectory of anticipation and failure. Statements such as "only doctors know about these things" or "we keep hearing about it" convey that the meshing of science and society do not necessarily reconcile the two, and also result in new hierarchies and "distributions" (Mol 2002, 87) of knowledge and expertise between public and epistemic collectives.

Ethnographic work on patient activism provides a starting point in thinking about the possible reconfiguration of such asymmetric bodies of power. As Roy Porter's (1985) foundational article on grassroots health care conveys, the rise of biocapitalism parallels the rise of a “medical history from below." Porter's language is indicative of previous modalities of patient politics, which consisted 
mainly of resistance rather than participation in technological progress. Recent scholarship moves beyond such opposition by showcasing the multilayered fabric of biosociality (Rabinow 1992) and the political capacity of patients for inclusion in governmental decision-making (Epstein 2007a) as well as the research agendas of scientific institutes (Callon and Rabeharisoa 2008; Koay and Sharp 2013).

Shortly after my interview with M., I made contact with CING and arranged to meet one of its chief scientists to learn more about the specifics of gene therapy and thalassemia in Cyprus. The CING building is situated near the center of Nicosia, in proximity to the green line that divides the city, and the island, in two. ${ }^{2}$ On entering, my eye meets an interior courtyard where stacks of inner balconies unfold in a wide expanse of linoleum floors and bleached white walls. It is late on a Friday afternoon and by now most people have left. The laboratory bench where I sit is covered with scientific instruments: microscopes, test tubes, and a fridge for keeping samples in the far corner. The hum of a shaker, a boxshaped machine used to mix chemical solutions, is constant in the background. Dr. V. enters the room, shuffles some papers, takes a folder, and leaves again. "Right now," he says when he finally sits down on a stool nearby, "we're part of a network of research centers working together to make a breakthrough." He goes on: "There's some competition from some other centers and research clusters, but that's healthy in many ways. Here in Cyprus we have a good thing going. CING is a thalassemia reference point for the WHO. And the PTA is active too." When I ask him about the relationship between the PTA and CING, he reflects:

What's quite impressive is that many of the patients have incredible knowledge as to what happens in the scientific field. CING might be part of the research, of experimentation, of therapy, but we are still part of this community. I would say that, by now, we [and the PTA] can't function without each other. And then you have the need for funding. We are lucky to have a good relationship with the Cypriot state; they fund most of our projects. So, what I'm trying to say is that research is always interactive. There's no point locking yourself in a laboratory saying that you're going to conduct research, or discover a gene, or something along those lines. To do research you need friends - to put it that way. You never do research on your own.

Friendship, although largely maintained and enacted through a network of committees and meetings between CING, the PTA, and the Cypriot Ministry of Health, is most vividly manifested in events such as workshops and conferences. On one occasion, Dr. V. invited me to a conference that was part of Thalassemia 
Week, which takes place annually and has been co-organized by the PTA since 1976. A CING scientist conducting research on gene therapy gave one of the presentations, and at the end of the talk, audience members had the opportunity to ask questions. Discussion ensued on whether a therapeutic DNA used in gene therapy should be frozen and thawed or directly injected. On the one hand, freezing therapeutic genes acts as a test of whether they are robust enough, and consequently whether injecting them into the host will prove successful. On the other hand, freezing and thawing the material potentially decreases its potency by killing off a proportion of the therapeutic cells.

The presenter, speaking in favor of freezing, conceded that this remained a sensitive, unresolved subject requiring further tests and even actual implementation. He concluded by saying that "you can't really know until you actually put it in practice - you can't control everything in the laboratory.” Despite such an agnostic statement, the debate carried on for several minutes and extended beyond the actual issue of freezing and thawing genes. As one thalassemia patient in the audience said: "If a freezing-and-thawing route is to be implemented in the future, then it must be made certain that the place where thawing takes place is in proximity to the location where the injections will take place. Otherwise, the therapeutic potency of the genes could be further damaged." Another audience member commented that this "went back to the issue" of a new transplantation center being built near CING headquarters and the need for the Cypriot state to secure the funds to complete it.

This exchange effected a shift in my ethnographic understanding of gene therapy in Cyprus. I came to see the conference as a site used to "convert uncertainty into risk," thus providing the PTA with an "opportunity to collaborate, experiment, and aspire in the public domain" (Appadurai 2013, 129). Moreover, the conference was an occasion demonstrating "the generative potential of uncertainty" (Berthomé, Bonhomme, and Delaplace 2012, 132) that is inherent to social relations and, in this case, politico-epistemic relations. At the same time, the conference was an event showcasing how uncertainty was not only produced but also confined through specific objectives and narratives of the future. In other words, the prospect of gene therapy was not addressed at the level of scientific accuracy, but according to the political, logistical, and infrastructural predicaments surrounding its actual implementation. Uncertainty did not usher conference participants into a liminal space of waiting or hoping for a breakthrough in gene therapy, but was rather reterritorialized in the context of Cypriot health care and the political activities of the PTA. 


\section{STAYING ACTIVE}

The PTA's relationship with the Cypriot state extends back to the founding of the organization in 1973. In the decades leading up to the creation of the PTA, both public knowledge and the treatment of thalassemia in Cyprus were at a rudimentary stage. Incidents of thalassemia were often mistaken for malaria or leishmaniosis. More important, patients faced heavy stigmatization, even by their own kin. When the Cypriot Ministry of Health commissioned an American anthropologist to conduct research on the psychosocial aspects of thalassemia in 1976, she concluded: "In Cyprus, the birth of a thalassemic child reflects adversely on the entire family and jeopardizes future alliances . . . the Cypriot thalassemic child is unwanted - unwanted by a family which is tainted by the child's very existence and unwanted by a medical system which is unprepared" (Book 1980, 57). Prior to the establishment of the PTA and the founding of the Cypriot Republic in 1960, no treatment for thalassemia existed in Cyprus. Blood used for transfusions was usually acquired from family members willing to help, or even bought. Cyprus was also mostly rural and a lack of public transportation and roads meant that parents living in villages had to hitchhike with their ill children to make the trip to Nicosia, the only place to receive treatment at the time. "We got by" ( $\varepsilon \theta \kappa \imath \alpha \beta a i v \alpha \mu \varepsilon)$ is the Greek Cypriot idiom that several thalassemia patients used to describe the uncertainty of day-to-day treatment in those days.

Thalassemia patients in Cyprus escaped such enforced presentism and fatalism through politicization, rendering the future available to contest as a horizon of action. A public sensitization campaign led by the PTA from 1972 to 1977, which included the distribution of informational material and talks in villages and schools, proved decisive in raising public awareness of thalassemia, alongside mounting pressure on the Cypriot state to improve treatment facilities. Once a breakthrough was made in genetic-testing technology in 1983, the PTA convinced the Cypriot Christian-Orthodox Church to introduce a compulsory certificate stating that couples had to undergo testing for the thalassemia allele and become aware of their status as potential carriers prior to getting married. ${ }^{4}$ This historical trajectory by which thalassemia became integrated into Cypriot society hence correlates with the emergence of the PTA as a political entity and registers the alliances fostered between the PTA, the Cypriot government and church, and subsequently with scientific bodies such as CING (Kyriakides, forthcoming).

The political objectives of the PTA have since changed. As several PTA members said to me, the organization must now advocate for the reform of an archaic health-care system that addresses issues of mortality but not quality of 
life. One PTA member explained: “The state system is stuck in the seventies, when the issue for us was to stay alive, but this is not the case anymore. We don't want simply to stay alive; we want to lead a normal life with as little treatment as possible. The issue we face is not life or death, but rather living." Amid such hopes and desires for normality and therapeutic finality, the prospect of gene therapy promises a version of the future free of transfusions, dialysis, and medication side effects.

The alliance and narrative that emerged from the conference I attended at CING's headquarters - namely, that the PTA sought to persuade the Cypriot state to equip the health-care system to carry out gene therapy - also surfaced in several interviews with individual interlocutors. About two weeks after the conference, I spoke with the president of the PTA at its offices in Nicosia. When I asked her about the prospect of gene therapy in Cyprus, K., the association's president, seemed positive. She stated that "CING is on a very good track. They have already created vectors capable of entering the human organism and distributing healthy genes. They are still in an experimental stage, but are very close to making a breakthrough." She went on to explain that even though the PTA cannot participate in the scientific aspect of research on gene therapy, it nevertheless puts pressure on the state to prepare an infrastructure capable of receiving gene therapy once it becomes available. This infrastructure demands that, first, a transplantation center tailored to carry out the genetic targeting required for gene therapy should be established either near or inside CING's headquarters and, second, that the Cypriot state should be prepared to fund all eligible thalassemia patients in Cyprus to undergo gene therapy once it becomes available. As she explained:

With the current infrastructure, [gene therapy] cannot take place in the existing general hospital. You need a lab that will be close to CING, and will be specialized in carrying out this sort of treatment. Plus, the amount of money required is huge. It is estimated that the cost of treating one patient with gene therapy will be around $€ 500,000$. And there are six hundred of us around the island. It's not easy. But we think the state is positive with regard to this prospect, as long as it secures the funds to do so.

Two days after I spoke to K., I sat in the thalassemia clinic in Nicosia chatting with another PTA member during his transfusion. He reiterated the emphasis that the PTA places on preparing the infrastructure for gene therapy, but stressed that attention and action must often be diverted to other fronts: 
CING is doing a really good job on the experimental front [of gene therapy]. We try and keep pressure on the state to build a new transplantation center, ideally inside CING. We apply pressure through CING — we have one of ours on their committee - and we also liaise regularly with the Ministry of Health through our own committee. But we have other stuff going on as well: a lack of blood, access to medication, treatment costs, and more. So we can't really focus our attention on gene therapy all the time, as there are often more urgent issues that we need to keep asking the state to address.

What I realized after interviewing several association members was that the committees and events used as mechanisms for applying pressure to the Cypriot Ministry of Health were often aimed at maintaining the prospect of certain goals, rather than achieving them. To quote another PTA member:

The state has generally been helpful and responsive. There still is much room for improvement, but they're not deaf to our demands. But we have to stay active. One of the reasons the PTA has a good relationship with the state is exactly because we have been in constant communication ever since the 1960s, when the PTA was founded.

The necessity to "stay active" was also conveyed to me in a conversation I had with a CING scientist. As he explained:

In a way, research sets its own agenda. You need to keep your ears open as to what is happening around you. A lab, especially one of the caliber of CING, cannot be static. You need to keep moving, and stay attuned to what happens around you - new information, new technologies, new breakthroughs, and so on. This whole thing, thalassemia, is a living organism, which evolves. You can't stay static. If you stay static, you're done for.

The importance of constant political pressure likewise became evident during another conference arranged by CING and the PTA, which the Cypriot minister of health also attended. In his brief speech, the minister clearly indicated that the PTA's request for a new transplantation center would not materialize due to "lack of funds" and departed from the site of the conference soon after. When I approached one of my key informants to ask his opinion about what had been said, he replied: "I expected him to say that. It doesn't mean we will stop advocating. We'll reconvene and see how to approach the matter." 
"Lack of funds" has become a skeleton key for state representatives, used to defuse the demands of groups such as the PTA, not only in Cyprus but also elsewhere in the world. The inability of a weakened state apparatus to respond to the demands of thalassemia patients burdens the PTA with formulating a political agenda capable of practically addressing the issue of establishing gene therapy in Cyprus. Such a task becomes increasingly difficult when one considers the epistemic opacity that surrounds gene therapy and the uncertainty of its arrival. The circulation of a particular narrative through mediums such as conferences and joint committees is a tactic (Kyriakides 2016, forthcoming) used by the PTA to establish a line of communication with Cypriot health-care officials. Below, I delve into the political work completed through this narrative as deployed by the PTA. In doing so, I focus less on what one says and more on the position one speaks from. In other words, I am interested in the position one must occupy in a milieu of uncertainty and technological advancement for certain narratives of the future to emerge and attain political force. I explore these questions through another element essential to PTA's activism and politics: subjunctivity.

\section{THE SUBJUNCTIVE INVERTED}

In his work on patient narratives, Byron Good $(1994,146)$ uses the term subjunctivity to refer to verbal declarations conveying "imagistic elements that suggest indeterminacy and openness to possibility and the potential for change." Before him, Victor Turner $(1977,71)$ contrasted the indicative mood, which expresses an act or state as "actual," with that of the subjunctive mood, which "tends to express desire, hypothesis, supposition, possibility: it may or might be so." In her ethnography of sonograph imaging in Vietnam, Tine Gammeltoft (2013, 170) similarly suggests that "bringing into analysis the subjunctivity and orientation toward the future that characterizes human endeavors is an important anthropological task." While I agree that subjunctivity is predicated on maintaining receptivity toward possibility and open-endedness, I suggest that we can gain a more nuanced ethnographic understanding of the way the subjunctive operates by focusing on two of its other dimensions: first, the sociopolitical and also existential dynamics of contestation and alliance through which subjunctivity emerges; and second, the manner in which subjunctivity gives way to narratives of a future capable of organizing, rather than simply cultivating, possibility.

As Good (1994, 148) observes, "the maintenance of competing plots [is] a strategy for subjunctivizing reality.” The competition between future plots was something I often encountered when speaking to PTA members regarding the 
prospect of gene therapy. Subjunctivity would usually manifest itself as an afterword of pessimism to a previous declaration of hope or, on the contrary, a punctuation of hope to a previously pessimistic statement. Take, for example, the PTA's president statement that the state is "positive" about the prospect of gene therapy "as long as it procures the funds to do so." In another example, a PTA member conveyed the promise of gene therapy as plausible, yet also a race against time:

Now I'm almost forty, and no cure has yet been found. But we remain hopeful. We don't expect miracles - we know it takes time to achieve results. The people at CING know what they are doing. What's important for us as a patients' association is to keep reminding the state that we need to be ready once the therapy becomes available. We can't waste time. If they manage to make the breakthrough tomorrow and then we need five or ten more years to set up the infrastructure for it, it's no good. We can't risk that.

After a pause, he went on to add: "Many of us are already old. Who knows if the therapy will work on us?"

In such narratives and depictions of the future, possibility does not result from remaining positive about the premise of change and transformation; rather, it emerges through a tension between hope and pessimism (Tutton 2011). In another interview, after it was once again made clear to me that gene therapy could potentially have age restrictions, I inquired as to why the PTA was so heavily invested in it, since the majority of its members were already in middle age. My interlocutor was quick to respond:

Perhaps it won't work for some of us, but you could say that for many putting pressure on the state for gene therapy is a matter of altruism and responsibility to future thalassemia patients. Besides, who said that all those involved in the association have lost their chance at being cured? Science takes leaps. Maybe when the bloody thing finally arrives, it won't have any age restrictions.

She concluded on a subjunctive note: "Hope dies last!"

It soon became apparent that patients who belonged to the PTA perceived the elusive technology of gene therapy differently from those who did not. For example, we can contrast the subjunctive marriage of pessimism and hope to the indicative statement made by M.'s friend that the breakthrough will come "from 
elsewhere." Oscillation between pessimism and hope is not necessarily an indication that one remains unable to imagine what the future holds. Pessimism and hope, as active ingredients of subjunctive narrativity, are both modes of imaginative thinking that etch the future in their own way. They both provide boundaries by which spaces of possibility are organized, and by which specific routes to the future unfold.

As Susan Reynolds Whyte $(2002,183)$ states, subjunctivity involves "the conditionality of being implicated with other people - not only 'know-how' regarding one's circumstance and illness, but also the 'know-who.'” By exploring differing degrees of social and political capital deployed by HIV patients in Uganda, Whyte showcases how different visions and routes to therapy are formed or not formed, depending on the alliances a patient cultivates. Correlatively, the interactions between the PTA, CING, and the Cypriot state convey that pursuing one's future is mostly a matter of practically organizing, managing, and deploying one's arsenal of relations and alliances_—what Morten Nielsen $(2011,400)$ calls "relational outreach" — to pursue desired outcomes. Events such as PTA conferences and workshops, as well as dialogues with patients, showcase how subjunctivity relationally crystallizes through everyday events, happenings, and encounters. For PTA members, this is the process by which the future becomes available. Due to their relations and alliances with CING and the Cypriot state, the narratives of PTA members emerge from and take place within the trajectory of technological progress in gene therapy, rather than outside of it. The narrators, in Good's $(1994,153)$ words, "are in the midst of the story they are telling."

In PTA members' narratives of the future, two forms of gene therapy dovetailed with and informed each other. On the one hand, gene therapy was narrated as an ambivalent, enigmatic technology; on the other, gene therapy was narrated through the political processes and relations of a network of organizations that, in their interactions, constitute the political economy of a potential breakthrough. Despite recent technological and scientific advancements in the field of gene therapy, the PTA and CING mostly make the leap from the indicative to the subjunctive through the latter, sociopolitical conceptualization of gene therapy.

\section{THE PRAGMATICS OF NARRATIVE IN AN AGE OF UNCERTAINTY}

Subjunctivity thus demands participation in a social field that remains processually alive. As suggested by one CING scientist, thalassemia in Cyprus requires one to "keep moving" in order to keep up with its social and technological gen- 
erativity. Similarly, as one PTA member put it, the association must "stay active" and maintain communication and pressure on the Cypriot state. Thalassemia and gene therapy in Cyprus can thus be conceptualized as "motion squared," to use Henrik Vigh's (2009) term - a milieu wherein both people and their surrounding social and technological landscapes undergo constant change.

In this context, it is critical to acquire the means necessary to construct images of the future that are capable of withstanding and organizing such a constantly shifting landscape. Laura Bear (2016) has recently urged anthropologists to address the contradictory and multifaceted dimensions of contemporary capitalist timescapes and how these dialectically unfold. In taking up Bear's provocation, I suggest that, as a form of disjunctive synthesis or "suturing" (Bear 2016, 497), narratives mediate contradictions and inequalities inherent to contemporary temporalities. In so doing, they construct "drafts" (Corsín Jiménez 2018) of the future that are immanent to the present. The involvement of the PTA and the alliances it cultivates allow its members to construct and deploy a particular narrative and version of the future: the building of a transplantation center, ideally inside CING to expedite the process of gene therapy, and the allocation of the funds needed to support the therapy for all thalassemia patients in Cyprus.

While conducting fieldwork, I came to the realization that no Cypriot Greek equivalent for the word breakthrough seems to exist. During interviews my interlocutors would use the English term breakthrough or the Greek term for discovery $(\alpha v \alpha \kappa a ́ \lambda v \psi \eta)$. On several occasions, however, my informants deployed Greek

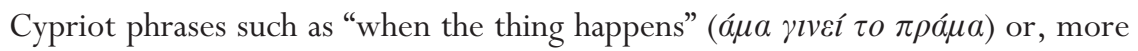

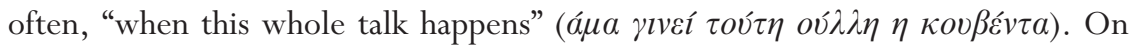
the one hand, the use of such local idioms denotes the prolonged trajectory of anticipation and also the failure of gene therapy to come to fruition as an applicable form of therapy. On the other hand, the prevalence of the notion of talk showcases how my informants' understandings of gene therapy extend beyond scientific notions of progress. Instead, understood as means of politically negotiating and contesting gene therapy in Cyprus, talk conveys the importance of narrative as a continuous form of activist praxis and technopolitical inclusion. Talk, as means of affirming specific narratives of the future and as enacted through occasions of conferences, meetings, and everyday conversations, has acquired a vitality that makes it an active component of thalassemia's political life in Cyprus.

Thus, during periods of frustration and discouragement resulting from a lack of progress, PTA politics, events, and collective sociality aimed specifically at reinforcing an activist narrative as a means of garnering governmental attention. 
As a PTA member once said regarding gene therapy: "We need to keep asking [the Cypriot state]. Not because we are greedy, but because thalassemia changes: technology improves, our needs change, and therapy methods improve." Narrative hence adopts the dual function of structuring the future and continuously recalibrating the relationship between present and future in the course of technopolitical change. As a means of "prefiguring" the future, narrative acts as a "condensed map of [a] contestable world" (Haraway 1997, 11).

A narrative might emerge from the pragmatics of alliance, but over time it can also acquire a pragmatic efficacy of its own - rendering it capable of generating events aimed at actualizing the image of the future it propounds (Gallagher 2017). As Elizabeth Povinelli (2014) puts it, "what is initially dispersed noise . . . comes to enclose itself through self-reference.” Ever since I began following the PTA's political activities in September 2012, the Cypriot economy has shown signs of recovery. Global research on gene therapy for thalassemia has produced significant outcomes, such as the successful treatment of seven patients (Finotti et al. 2015). In 2014, CING, in cooperation with a partner research center, commenced its own human trials in Italy, which included PTA members. The participation of the PTA and CING acknowledges global trajectories of technological advancement and strives to integrate them into the prevailing model of state-sponsored Cypriot health care. The strengthening of existing alliances and the deployment of PTA narratives connecting gene therapy to Cyprus and, more broadly, to the future forms an essential part of this process of technological localization. In a conference organized by the PTA in April 2017 under the auspices of the Cypriot Ministry of Health, it was announced that the Nicosia thalassemia clinic, which was first founded in 1981, would be revamped and moved to a new location that would house all treatment facilities. The poster circulated in the media to promote the conference displayed the logo of the association: one withered yellow poppy flower and one healthy red one, symbolizing rejuvenation, underscored by a swooshing blue arrow pointing forward. The image's caption read "Setting Our Sights on the Future: Thalassemia in Twenty-First-Century Cyprus." Some months later, in September 2017, the new president of the PTA stated in a radio interview and newspaper article that an official agreement had been signed between the PTA and CING in an attempt to develop in-house clinical trials for thalassemia gene therapy in Cyprus. In this interview, he affirmed that "the association's vision of the future is that old and new generations of thalassemia patients can have the best treatment possible" (Radio 99 FM 2017; author's translation). 
If the promise of breakthrough and the cultivation of a collective subjunctive mood constitute the imaginative means of producing possibility, the continuous circulation of narrative by the PTA is the means by which possibility is restrained, and a certain image of the future solidifies and acquires political potency. We can therefore understand the constant labor of affirming that narrative, while maintaining awareness of constant change and volatility through what Elizabeth Povinelli (2011) has termed embagination: a process by which the absolute immanence of the otherwise contained within the present is affirmed, but also confined to a single form. As Povinelli notes, this amalgam of compounded possibility is not completely insulated but rather one that, as with a woven bag, retains a porous connection to the outside. The bag is therefore capable of adapting to and integrating contingencies, but it also has the capacity to remain robust and durable in the face of internal and external assaults.

\section{CONCLUSION: Directing the Future}

The ethnographic milieu traversed in this article is one of uncertainty - a worldly dimension becoming increasingly pervasive in people's lives, one that has become central to anthropological discussions of the future (Samimian-Darash and Rabinow 2015; Salazar et al. 2017). Anthropologists surveying the future largely approach the manner by which people orient themselves in conditions of uncertainty through notions of hope, waiting, patience, and endurance. Although such conceptual stances address the active positions that people immersed in uncertainty often adopt, they largely treat the notion of the future as an abstract horizon of unknowability and contingency (but see Jansen 2016). In doing so, such conceptual paradigms emphasize reactive practices of handling and orienting amid uncertainty. They underemphasize the ways by which people regulate the space of possibility out of which uncertainty emerges by endowing specific versions of the future with political gravitas. By focusing on the pragmatics of relations and alliance, I have attempted to show how practices of future-making and dwelling amid uncertainty can be further activated and supplemented by practices that seek to clarify and define the abstract notion of the future, giving rise to a sense of direction regarding "what can be done" (Whyte 2002, 179).

I have used the breakthrough as a focal point and contemporary keyword through which patient ambitions emerge and, through time, attain a tangible quality of anticipation. The sociopolitical embeddedness through which expectations of breakthrough acquire consistency gestures to the manner in which people immersed in conditions of uncertainty and waiting come to discern and cultivate 
specific narratives of the future. If people patiently hope, wait, and endure, it implies that, despite conditions of uncertainty, they still draw power and, perhaps more importantly, direction, from somewhere. Tracing the structural dynamics of alliance that make such practices politically potent and practically meaningful is of great importance. As demonstrated by the varying positionalities that thalassemia patients in Cyprus adopt in considering the prospect of gene therapy, visions of the future vary according to alliances entertained and positions occupied by individuals in sociopolitical structures (Green 2012). Whether actors wield more or less practical and political influence may depend on the mastery they have developed in using and deploying their relational capital. Once we acknowledge such variations of relationality and alliance, an analytic inversion takes place: hope, patience, endurance, and waiting are not the starting points, but the endpoints of ethnography. If "hope dies last," as the motto suggested by one of my informants goes (see also Zigon 2009), it is because everything else that sustains hope-all the relationships, alliances, and structures that contain, sustain, and nourish it_ die before it.

The PTA's position within the politics of thalassemia in Cyprus reveals how grassroots activism deserves more attention than it has thus far received within the emerging anthropology of uncertainty and the future. The same must be said for the epistemologies and imaginaries of the breakthrough. The political landscape of gene therapy and thalassemia in Cyprus offers a case in point and may even prove exemplary. The lack of a definitive path toward the arrival of a breakthrough imbues the thalassemic future not only with the active passivity of waiting or hoping but also with political vitality. This vitality emerges through a generative tension, created and enacted in the in-between of political dispute, on the one hand, and uncontrolled yet anticipated technological progress, on the other.

Moreover, we can refine our anthropological understanding of subjunctivity in attending more carefully to the structural and relational dynamics by which it gathers force. The interactions between the PTA, CING, and the Cypriot state show that subjunctivity demands imbrication in a milieu of alliance, dispute, and knowledge production. Subjunctivity, in this sense, is not a vague mood or propensity toward future possibility and change, but a collective sentiment that can actively partake in the processes by which the future is politically negotiated. The existential dimensions of subjunctivity and future-making index the fact that, for the PTA, subjunctivity emerges from the collective realization of being immersed in a milieu of possibility that, unless controlled, can betray all those caught within 
it. Hence, subjunctivity results not only from the political necessity of maintaining the continuous generation of hope but also from developing the means of remaining “ontologically secure, and in command of one's own life" (Jackson 2002, 144).

The construction and deployment of politicized narratives of the future are one means by which possibility is not only produced but also managed. For patients worldwide, the grip of pharmaceutical capitalism and the weakening of state apparatuses mean that the politics of patient organizations cannot always have success as their objective. The anticipation of breakthroughs demands instead a coordinated epistemology, imaginary, and politics where importance is placed not only on what can be achieved in the present but also on which narratives of the future persist over others. Given the epistemic opacity and political uncertainty surrounding gene therapy in Cyprus, the PTA engages in the continuous political labor of affirming a narrative of governmental investment - a narrative through which the present can be diffracted, contested, and planned. As such, the PTA's long-term political strategy differs from that described by Arjun Appadurai $(2013,190)$ in his ethnography of housing activists in Mumbai, which is one of "cumulative victories and long-term asset building." Rather, the PTA's political objective is the prolonged maintenance of a "materialized narrative field" (Haraway 1997, 33) through which technologies and futures alike can emerge and take shape.

Alliance, subjunctivity, and narrative constitute the three ingredients of a process I have labeled directing the future: a form of relational, political futuremaking that repeatedly deploys the image of a constructed future as a point of reference to direct attention to specific objectives that are deemed achievable. The PTA has creatively and persistently pursued such a project. As such, the political practices of the PTA are not merely grounded in the abstract hope for the future arrival of gene therapy. They are instead firmly rooted in and attuned to the unfolding of a breakthrough. These are practices emergent from, and actively generative of friction between the present and the unveiling of its insufficiencies, which make a given future improbable or incompatible. Through such practices, the PTA locates and organizes the dynamics of a trajectory of possibility. Such a mode of politics and future-making does not merely anticipate a future but also presses the present and nearing future toward reconciliation. 


\section{ABSTRACT}

Gene therapy is a technology that involves the introduction of therapeutic genes into humans for the replacement of mutations causing disorders. This article stems from research conducted with a thalassemia patients' association in Cyprus and explores how political and epistemic uncertainty surrounding the promise of breakthrough in gene therapy is harnessed to particular objectives and narratives for the future. Anthropologists who survey the future largely address the manner in which people orient themselves in conditions of uncertainty through concepts of hope, waiting, patience, and endurance. Less attention has been paid to how people construct and deploy narratives and images of the future in a way that can bridge present immediacy and abstract futurity - a process I call directing the future. The concept I use to elucidate the connections between breakthrough and narrative is that of subjunctivity. In juxtaposing different positionalities that thalassemia patients in Cyprus adopt with regard to the promise of gene therapy, I show that subjunctivity is not only the ability to be receptive to transformation and the possibility of a world otherwise. The intersubjective and political processes out of which subjunctivity and narrative emerge are also the processes by which an otherwise undefined future becomes ordered, and certain images of the future attain more gravity and reality than others. [future; subjunctivity; uncertainty; hope; waiting]

\section{NOTES}

Acknowledgments This article has gone through several iterations and received numerous sets of comments. I especially thank Jeanette Edwards, Maia Green, Peter Wade, Soumhya Venkatesan, and María Puig de la Bellacasa for their critical feedback and suggestions. I am also grateful to the Cultural Anthropology reviewers and the editorial collective, especially James Faubion, whose careful guidance and expertise proved crucial in further developing and clarifying key concepts of the article. This research benefited from a University of Manchester Postgraduate Fieldwork Bursary and a Sutasoma Award from the Royal Anthropological Institute of Great Britain and Ireland.

1. All quoted speech presented in this article is drawn from research conducted in Cypriot Greek. English translations are my own.

2. The prevalence of thalassemia is the same in Northern Cyprus. Patients from the north often visit the south to receive their treatment because of better health-care facilities there. If a patient from Northern Cyprus visited the thalassemia clinic in the south of Nicosia, I was often told that he or she was allowed to "cut the line" in the transfusion schedule for immediate treatment. This arrangement, implemented by the Cypriot state, exasperated some patients while others agreed with it. It never became a matter of political dispute during my fieldwork.

3. The PTA was founded by a number of parents of thalassemia patients, whose children at the time were still relatively young. As Steven Epstein (2007b, 504) notes, the process of patient associations founded by kin members and then passed on to patients themselves as they mature has been a common phenomenon of early patient activism.

4. Although the Cypriot premarital certificate has created considerable discussion among bioethicists, it is accepted almost unanimously among Cypriots. For a comprehensive discussion of ethical and legal issues, see Cowan 2008, 181-222. 


\section{REFERENCES}

Addison, Courtney

2017 "Spliced: Boundary-Work and the Establishment of Human Gene Therapy." BioSocieties 12, no 2: 257-81. https://doi.org/10.1057/biosoc.2016.9.

Angastiniotis, Michael, Sophia Kyriakidou, and Minas Hadjiminas

1986 "How Thalassemia was Controlled in Cyprus." World Health Forum 7, no. 3: 29197. http://www.who.int/iris/handle/10665/47620.

Appadurai, Arjun

2013 The Future as Cultural Fact. Essays on the Global Condition. New York: Verso.

Barad, Karen

2007 Meeting the Universe Halfway: Quantum Physics and the Entanglement of Matter and Meaning. Durham, N.C.: Duke University Press.

Bear, Laura

2016 “Time as Technique." Annual Review of Anthropology 45: 487-502. https://doi. org/10.1146/annurev-anthro-102313-030159.

Berthomé, Franois, Julien Bonhomme, and Grégory Delaplace

2012 "Preface: Cultivating Uncertainty." HAU 2, no 2: 129-37. https://doi.org/ 10.14318/hau2.2.008.

Biehl, João, and Peter Locke

2010 "Deleuze and the Anthropology of Becoming." Current Anthropology 51, no. 3: 317-51. https://doi.org/10.1086/651466.

Book, Patricia Ann

1980 "Thalassemia: An Anthropological Study of Eighty-Six Patients and Their Families in Cyprus.” $\mathrm{PhD}$ dissertation, University of Connecticut. https:// opencommons.uconn.edu/dissertations/AAI8025344.

Brun, Cathrine

2015 "Active Waiting and Changing Hopes: Toward a Time Perspective on Protracted Displacement." Social Analysis 59, no. 1: 19-37. https://doi.org/10.3167/sa. 2015.590102.

Callon, Michel, and Vololona Rabeharisoa

2008 "The Growing Engagement of Emergent Concerned Groups in Political and Economic Life: Lessons from the French Association of Neuromuscular Disease Patients." Science, Technology, and Human Values 33, no. 2: 230-61. https:// doi.org/10.1177/0162243907311264.

Corsín Jiménez, Alberto

2014 “Introduction. The Prototype: More than Many and Less than One." Journal of Cultural Economy 7, no 4: 381-98. https://doi.org/10.1080/17530350.2013. 858059 .

2018 "Drafts." In "Keywords for Ethnography and Design," Theorizing the Contemporary series edited by Cassandra Hartblay, Joseph D. Hankins, and Melissa L. Caldwell, Cultural Anthropology website, March 29. https:// culanth.org/fieldsights/1348-drafts.

Cowan, Ruth

2008 Heredity and Hope: The Case for Genetic Screening. Cambridge, Mass.: Harvard University Press.

Epstein, Steven

2007a Inclusion: The Politics of Difference in Medical Research. Chicago: University of Chicago Press.

2007b "Patient Groups and Health Movements." In Handbook of Science and Technology Studies, 3rd edition, edited by Edward J. Hackett, Olga Amsterdamska, Michael Lynch, and Judy Wajcman, 499-540. Cambridge, Mass.: MIT Press.

Finotti, Alessia, Laura Breda, Carsten Lederer, Nicoletta Bianchi, Cristina Zuccato, Marina Kleanthous, Stefano Rivella, and Roberto Gambari

2015 "Recent Trends in the Gene Therapy of $\beta$-thalassemia." Journal of Blood Medicine 6: 69-85. https://doi.org/10.2147/JBM.S46256. 
Franklin, Sarah

1998 "Making Miracles: Scientific Progress and the Facts of Life." In Reproducing Reproduction: Kinship, Power, and Technological Innovation, edited by Sarah Franklin Gallagher, Shaun and Helena Ragoné, 102-117. Philadelphia: University of Pennsylvania Press.

2017 "The Narrative Sense of Others." HAU 7, no 2: 467-73. https://doi.org/ 10.14318/hau7.2.039.

Gammeltoft, Tine M.

2013 "Potentiality and Human Temporality: Haunting Futures in Vietnamese Pregnancy Care.” Current Anthropology 54, S7: S159-171. https://doi.org/ 10.1086/670389.

Ginsburg, Faye D., and Rayna Rapp, eds.

1995 Conceiving the New World Order: The Global Politics of Reproduction. Berkeley: University of California Press.

Good, Byron

1994 Medicine, Rationality, and Experience: An Anthropological Perspective. New York:

Green, Sarah Cambridge University Press.

2012 "Reciting the Future: Border Relocations and Everyday Speculations in Two Greek Border Regions." HAU 2, no. 1: 111-29. https://doi.org/10.14318/ hau2.1.007.

Guyer, Jane I.

2007 "Prophecy and the Near Future: Thoughts on Macroeconomic, Evangelical, and Punctuated Time.” American Ethnologist 34, no. 3: 409-421. https://doi.org/ 10.1525/ae.2007.34.3.409.

Hage, Ghassan

2009 "Waiting Out the Crisis: On Stuckedness and Governmentality." In Waiting, edited by Ghassan Hage, 97-106. Carlton, Australia: University of Melbourne Press.

Haraway, Donna J.

1997 Modest_Witness@Second_Millennium.FemaleMan ${ }^{\mathbb{0}}{ }_{\text {Meets_OncoMouse }}{ }^{\mathrm{TM}}: \quad$ Feminism and Technoscience. New York: Routledge.

Helmreich, Stefan

2009 Alien Ocean: Anthropological Voyages in Microbial Seas. Berkeley: University of California Press.

Jackson, Michael

2002 "Biotechnology and the Critique of Globalization." Ethnos 67, no. 2: 141-54. https://doi.org/10.1080/00141840220136792.

Jansen, Stef

2016 "For a Relational, Historical Ethnography of Hope: Indeterminacy and Determination in the Bosnian and Herzegovinian Meantime." History and Anthropology 27, no. 4: 447-64. https://doi.org/10.1080/02757206.2016. 1201481.

Jensen, Casper Bruun

2013 "Two Forms of the Outside: Castaneda, Blanchot, Ontology." HAU 3, no 3: 309-335. https://doi.org/10.14318/hau3.3.013.

Koay, Pei P., and Richard A. Sharp

2013 "The Role of Patient Advocacy Organizations in Shaping Genomic Science." Annual Review of Genomics and Human Genetics 14: 579-95. https://doi.org/

Kuhn, Thomas 10.1146/annurev-genom-091212-153525.

1962 The Structure of Scientific Revolutions. Chicago: University of Chicago Press. 
Kwon, June Hee

2015 "The Work of Waiting: Love and Money in Korean Chinese Transnational Migration.” Cultural Anthropology 30, no. 3: 477-500. https://doi.org/ 10.14506/ca30.3.06.

Kyriakides, Theodoros

2016 "Tactics as Empirical and Conceptual Objects: Patient Activism and the Politics of Thalassaemia in Cyprus." Engaging Science, Technology, and Society 2: 13-32. https://estsjournal.org/index.php/ests/article/view/48/26.

Forthcoming "Tactics of Associations." Social Anthropology.

Miyazaki, Hirokazu

2004 The Method of Hope: Anthropology, Philosophy, and Fijian Knowledge. Stanford, Calif.: Stanford University Press.

Mol, Annemarie

2002 The Body Multiple: Ontology in Medical Practice. Durham, N.C.: Duke University Press.

Nielsen, Morten

2011 "Futures Within: Reversible Time and House-Building in Maputo, Mozambique." Anthropological Theory 11, no. 4: 397-423. https://doi.org/10.1177/ 1463499611423871.

Nowotny, Helga, Peter Scott, and Michael Gibbons

2003 “Introduction. 'Mode 2' Revisited: The New Production of Knowledge." Minerva 41, no. 3: 179-94. http://www.jstor.org/stable/41821245.

Pels, Peter

2015 "Modern Times: Seven Steps toward an Anthropology of the Future." Current Anthropology 56, no. 6: 779-96. https://doi.org/10.1086/684047.

Petryna, Adriana

2010 "The Politics of Experimentality." In In the Name of Humanity: The Government of Threat and Care, edited by Ilana Feldman and Miriam Ticktin, 256-89. Durham, N.C.: Duke University Press.

Porter, Roy

1985 “The Patient's View: Doing Medical History from Below.” Theory and Society 14, no. 2: 175-98. https://doi.org/10.1007/BF00157532.

Povinelli, Elizabeth A.

2011 “Routes/Worlds." e-flux, no. 27. https://www.e-flux.com/journal/27/67991/ routes-worlds.

2014 "Geontologies of the Otherwise." In "The Politics of Ontology," Theorizing the Contemporary series edited by Martin Holbraad and Morten Axel Pedersen, Cultural Anthropology website, January 13. https://culanth.org/fieldsights/465geontologies-of-the-otherwise.

Procupez, Valeria

2015 "The Need for Patience: The Politics of Housing Emergency in Buenos Aires." Rabinow, Paul Current Anthropology 56, S11: S55-65. https://doi.org/10.1086/682240.

1992 "Artificiality and Enlightenment: From Sociobiology to Biosociality." In Incorporations, edited by Jonathan Crary and Sanford Kwinter, 234-52. New York: Zone Books.

Radio 99 FM

2017 “Interview with PTA President Milto Miltiadous." September 14.

Reed, Adam

2011 “Hope on Remand.” Journal of the Royal Anthropological Institute 17, no. 3: 52744. https://doi.org/10.1111/j.1467-9655.2011.01705.x. 
Ringel, Felix

2014 "Post-Industrial Times and the Unexpected: Endurance and Sustainability in Germany's Fastest-Shrinking City." Journal of the Royal Anthropological Institute 20, S1: 52-70. https://doi.org/10.1111/1467-9655.12093.

Rose, Hilary, and Steven Rose

2012 Genes, Cells, and Brains: The Promethean Promises of the New Biology. New York: Verso.

Salazar, Juan Francisco, Sarah Pink, Andrew Irving, and Johannes Sjöberg, eds.

2017 Anthropologies and Futures: Researching Uncertain and Emerging Worlds. New York: Bloomsbury.

Samimian-Darash, Limor, and Paul Rabinow, eds.

2015 Modes of Uncertainty: Anthropological Cases. Chicago: University of Chicago Press.

Sandoval-Cervantes, Iván

2017 "Uncertain Futures: The Unfinished Houses of Undocumented Migrants in Oaxaca, Mexico.” American Anthropologist 119, no. 2: 209-222. https: / /doi.org/ 10.1111/aman. 12864 .

Sunder Rajan, Kaushik

2006 Biocapital: The Constitution of Postgenomic Life. Durham, N.C.: Duke University Press.

Taussig, Karen-Sue, Klaus Hoeyer, and Stefan Helmreich

2013 "The Anthropology of Potentiality in Biomedicine." Current Anthropology 54, S7:

Thompson, Charis S3-14. https://doi.org/10.1086/671401.

2005 Making Parents: The Ontological Choreography of Reproductive Technologies. Cambridge, Mass.: MIT Press.

Turner, Victor

1977 "Process, System, and Symbol: A New Anthropological Synthesis." Daedalus 106, no. 3: 61-80. http://www.jstor.org/stable/20024494.

Tutton, Richard

2011 "Promising Pessimism: Reading the Futures to be Avoided in Biotech." Social Studies of Science 41, no. 3: 411-29. https://doi.org/10.1177/ 0306312710397398.

Vigh, Henrik

2009 "Motion Squared: A Second Look at the Concept of Social Navigation." Anthropological Theory 9, no. 4: 419-38. https://doi.org/10.1177/ 1463499609356044.

Whyte, Susan Reynolds

2002 "Subjectivity and Subjunctivity: Hoping for Health in Eastern Uganda." In Postcolonial Subjectivities in Africa, edited by Richard Werbner, 171-90. New York: Zed Books.

Zee, Jerry C.

2017 "Holding Patterns: Sand and Political Time at China's Desert Shores." Cultural Anthropology 32, no. 2: 215-241. https://doi.org/10.14506/ca32.2.06.

Zigon, Jarrett

2009 "Hope Dies Last: Two Aspects of Hope in Contemporary Moscow." Anthropological Theory 9, no. 3: 253-71. https://doi.org/10.1177/ 1463499609346986. 